STATE OF ILLINOIS

DEPARTMENT OF REGISTRATION AND EDUCATION

DIVISION OF THE

NATURAL HISTORY SURVEY

STEPHEN A. FORBES, Chief

Vol. XIII.

BULLETIN

Article X.

\title{
THE EUROPEAN CORN-BORER
}

AND SOME SIMILAR

NATIVE INSECTS

\author{
BY \\ WESLEY P. FLINT \\ and
}

JOHN R. MALLOCH

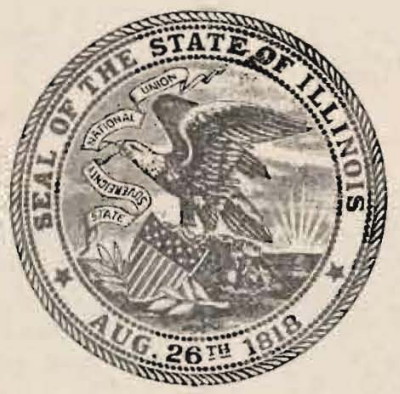

PRINTED BY AUTHORITY OF THE STATE OF ILLINOIS

URBANA, ILLINOIS

June, 1920 


\section{ERRATA}

Page 97, line 17, for first larval read pupal.

Page 112, in legend, for jonessi read jonesii.

Page 114, in legend', for or read of.

Page 125, line 4, for Bonosa read Bonasa.

Page 131, in legend, for hirundinaceus read hirudinaceus.

Page 138, last line, for coccoon read cocoon.

Plate XII, explanation page, next to last line, for acrivora read aerivora.

Plate XIII, explanation page, next to last line, for White-grubs read White-grub.

Page 293, Figure $5 a$ was reversed in printing, and the two items of the legend should change places.

Page 515, second table, for Pelocoris femorata read Pelocoris femoratus. 
Article X.-The European Corn-borer and some Similar Native Insects. By Wesley P. Flint and John R. Malloch.

The recent discovery in the eastern part of this country of the European corn-borer (Pyrausta mubilalis Hübner) and the possibility of its spread westward, has caused much alarm among farmers throughout the corn belt. The present publication is intended to give a few of the more important facts concerning this insect and some of the closely related native borers, and to supply a means of distinguishing them.
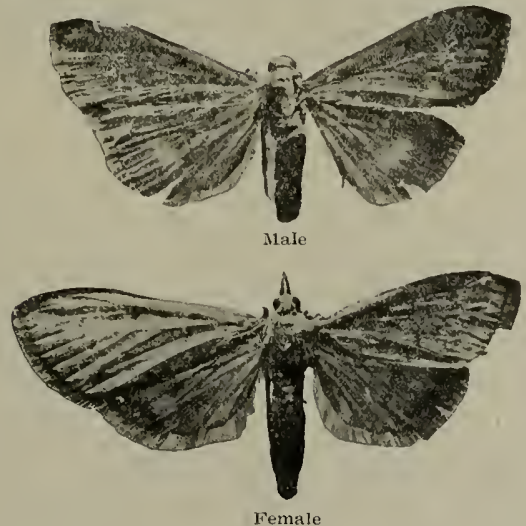

Fig. 1. European corn-borè (Pyrausta nubilalis Hueb.). Twice natural size.

\section{Discovery of the Corn-Borer and ArEa Infested}

This borer was first discovered in this country in a field of corn near Boston, Mass., during the summer of 191\%. It had probably been imported from Europe in shipments of broom-corn some eight or ten years before. In January of 1919 it was found near Schenectady, N. Y.. and late in the summer of 1919 in some of the lake counties in western New York. 
It has spread quite rapidly in Massachusetts since it was first discovered, and at present an area of about nineteen hundred square miles in the eastern part of the state is known to be infested, together with a few towns just over the line in New Hampslire. In New York there is an infestation of several hundred square miles in the vicinity of Schenectady, and a still larger area in the western part of the state in the counties bordering Lake Erie.

\section{INJURIES}

In Europe this insect periodically causes serious losses of corn, hops, millet, and hemp, and is known to feed on many other plants. There are records of destruction of 50 per cent. of these crops during years when the borers were abundant.

In this country the insect is already known to feed on over a hundred different plants, including nearly all of our cultivated crops. Corn is apparently preferred to all other plants, and is the most seriously damaged. The larva feeds on all parts of the plant above ground, including the leaves, stalk, tassel, stem of the ear, and ear. As many as $11 \%$ borers have been found in a single stalk of corn, and 15 in a single ear.

From our present knowledge of this insect, it is one of the most destructive which has ever been brought into this country, and seems capable of greater injury to corn than any of our native species.

\section{LIFE History}

The corn-borer passes the winter in the stems of its food plants as a nearly full-grown caterpillar. Nearly all the caterpillars remain in the stem above ground, but they are sometimes found below the surface where the larger parts of the stalk extend into the ground. They remain in a dormant condition until the weather becomes warm in spring, when a small percentage of them feed a little on the dry plants in which they passed the winter. All shortly change to the pupal or resting stage, and in the vicinity of Boston emerge as moths about May 15. The moths' have a wing expanse of a little over an inch, with yellow or yellowish red wings (Fig. 1) marked by irregular dark lines. They live from six to thirty-five days, and after mating the females deposit their eggs in small irregular masses, cemented together,- on the leaves of their food plants (Fig. 2). Each mass contains from five to fifty or more glistening white eggs. Each moth lays from two hundred to eight hundred eggs, the number laid by moths of the first generation being somewhat smaller than that of the second. The eggs hatch in from five to ten days. The small caterpillars feed externally for a short time and then enter the stems and the larger parts of the leaves (Fig. 3). They complete their growth in from thirty-five to sixty days, pupate in their food plants, and, in Massachusetts, emerge again as moths during July and August. These lay their eggs in the same manner as the first generation, and the 


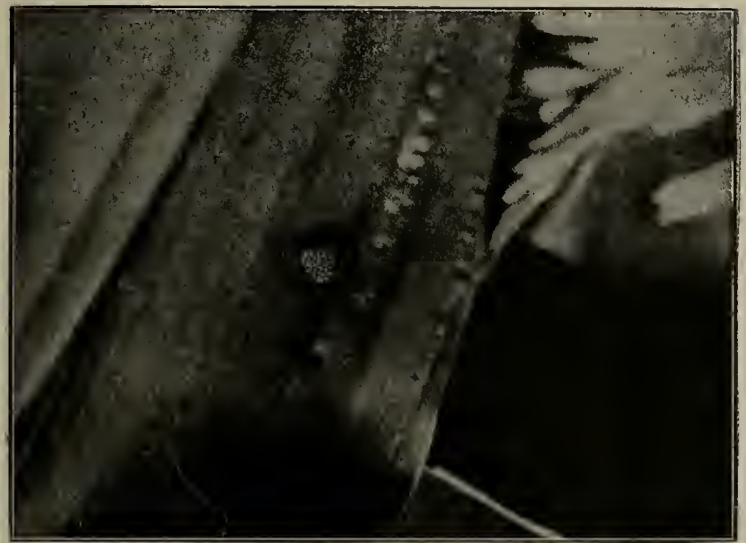

Fig. 2. Egg-mass of European corn-borer on leaf of corn ; natural size...

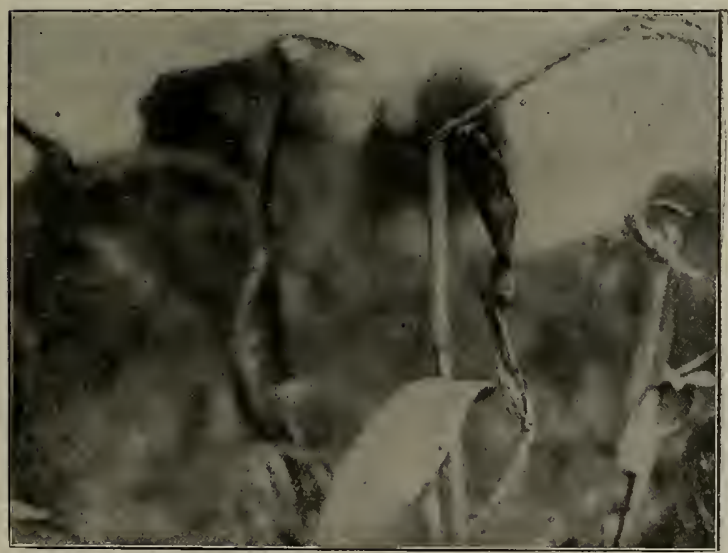

Fra. 3. Corn plants showing the characteristic breaking over of the tassel caused by the work of the European corn-borer. 
caterpillars hatching from them become full-grown on the approach of cold weather and hibernate in the stems of their food plants. Although there are two full annual generations of the insect in the Massachusetts area, there is only one in New York, owing, no doubt, to the colder climate. There would certainly be two generations in Illinois, and possibly three in the southern part.

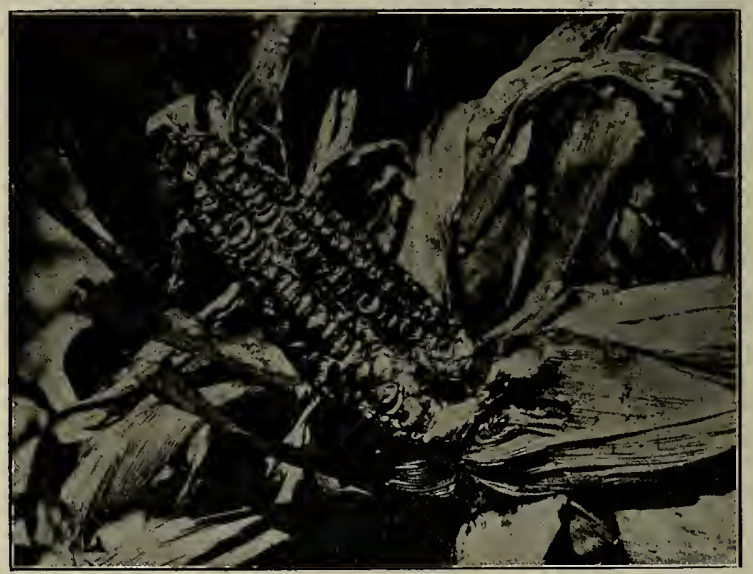

Fig. 4. Ear of corn infested by European corn-borer, showing the characteristic exudations of frass.

\section{Means of SPREAd}

The moths are fairly strong fliers, and have been observed to fly over two hundred and eighty-seven yards at a single flight; and as such flights are frequent, it would be easy for the insect to travel a considerable distance during the three or four weeks of its active life as a moth. It has, however, probably been established in new localities mainly while in the larval stage in the stems of its food plants. There is great danger of carrying it in this way from the infested territory, especially in shipments of broom-corn, hemp, celery, corn on the ear, etc., and more particularly in shipments of unshelled seed-corn. During the last few years large amounts of sweet corn on the ear have been shipped from points in the New England States near the known infested territory to canning factories located throughout the Middle Western States (Fig. 4 ) ; and perhaps the greatest danger of introducing the pest in the corn 
belt has come from these shipments. Any one knowing of such shipments having been made in the last two or three years should notify the Natural History Survey, Urbana, Ill., of fields where such shipments have been planted, and should keep a sharp lookout for the borer in their vicinity, or more particularly in the neighborhood of places where such corn may have been shelled, if there is any likelihood that all the cobs have not been burned, as the borers would probably be transported inside the cobs. Careful examinations have already been made in the vicinity of all canning factories where such corn was known to have been received, but so far no trace of the insect has been found in Illinois.

\section{Means of Control.}

At present no very effective means of controlling this insect are known. In fact, the only way by which its numbers may be appreciably reduced is by burning the plants in which it passes the winter. This is a very expensive operation, as the borers are found in the stems of practically all weeds, large grasses, and cultivated crops remaining on the ground after harvest, all of which must be completely burned up. This method of control was put to a thorough test in. the infested areas in New York and Massachusetts last year, with the result that the cost of clearing ordinary corn-stubble fields or land used for general truck crops was from $\$ 25$ to $\$ 50$ or more per acre. More extensive experimental work along this line is being done with improved machinery in Massachusetts this season (1919), and it is hoped to reduce materially the expense of this method of control. No adequate summer measures have been worked out. Spraying of food plants with arsenicals, while it affords some measure of control, does not kill a sufficiently large percentage of the borers to make it worth while.

\section{Native Borers Closely resembling the European CORN-borer}

There are several related species which closely resemble the European corn-borer, both in the appearance of all stages of the insects and in their work. The most abundant of these is commonly known as the smartweed-borer ( $P$. obumbratilis), which is found very commonly in smartweed throughout the entire state. The life history of this insect is approximately the same as that of the European corn-borer, there being two generations, the moths appearing in May and again the latter part of July, and the insect passing the winter as a full-grown larva in the stems of its food plants. Until the last two or three years, this insect was not generally known to infest corn, but investigations made during the past year have shown that it frequently winters in the corn plant. A single specimen was found in grèen corn growing in a very large patch of smartweed about July 1, 1919. This specimen, however, had evidently gone to the corn from a newly mown patch of smartweeds. 
and simply made a small hole near the base of the corn-stalk in which to pupate. Early in the fall of 1919 examinations carried on throughout the state showed that this borer commonly leaves the smartweed early

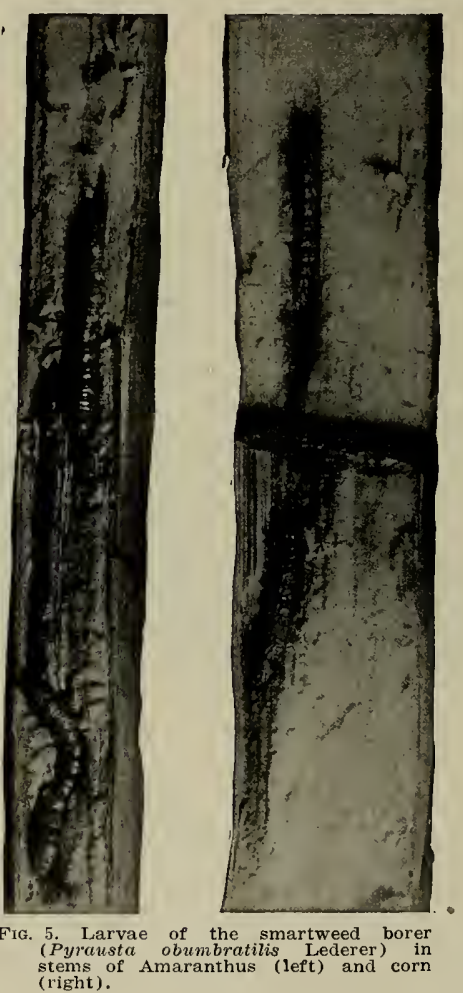

in fall, where the infestation is heavy, and migrates to corn (Fig. 5) and a number of other plants. We have never taken it in corn where the corn was growing more than thirty feet from infested smartweed. It apparently does no injury whatcver to the corn, simply boring a small gallery in the stalk in which to pass the winter, and it does not enter 
the corn plant until the ear is fully matured-in fact, generally not until the stalk is quite dry. Up to the present time this borer has been found in the fall in the stems of the following plants:

Smartweed................................

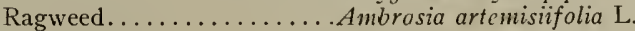

- Giant ragweed.............. trifida L.

Indian mallow.............Abutilon theophrasti Medic.

Jimson-weed............. Datura stramanium L.

Goldenrod............... Solidago sp.?

Lamb's-quarters............Chenopodium album L.

Barnyard grass.......... Echinachloa crus-galli Beauv.

Foxtail grass............ Setaria glauca Beauv.

Cocklebur...............Xanthium spinosum L.

Western tickseed sunflower. Bidens aristosa Britton

Common sunflower........ Helianthus anmus L.

Rough pigweed........... Amaranthus retroflexus L.

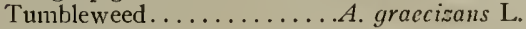

Prostrate pigweed.......... blitoides Wats.

Spanish needles............ Bidens sp.?

Wild lettuce.............Lactuca canadensis L.

Evening primrose.......... Oenathera biemis L.

Field corn.

Sweet corn.

This borer has not been found in any of the above weeds except where they were growing near infested smartweed, and apparently it goes to then in fall as a more desirable place to hibernate than the smartweed stems. It has not been found in the stems of any weeds where such stenis were hard and woody, although it may be abundant in the softer parts of the same plants. In some fields where the smartweed was very heavily infested, the borers were found fully as numerous in the stems of some other weeds, as is shown by the following comparative counts made in plants other than smartweed:

Corn ................. 20

Amaranthus retroflexus ........ 108

Lamb's-quarters ............. 19

Ragweed ............... 23

Smartweed .............. 99

Barnyard grass ............ 2

So far as can be learned from the observations this season, no real injury has been done by this native borer. Although as many as twenty
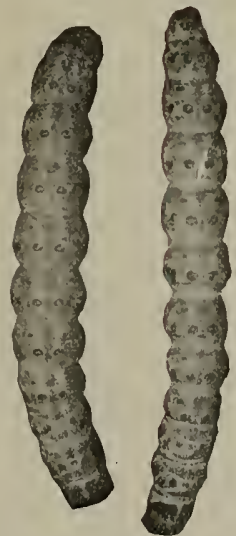

Fig. $5 a$ Larvae of the Smartweed European 
of the insects have been found in a single corn-stalk, and one in the stem of the ear of the corn, no injury to the corn had resulted.

Another closely related borer occurs in the stems of the Nelumbo or western water-lily or chinquapin ("yonkapin"). This species, so far as known, does not infest any other plant.

\section{OTHER INSECTS LIKELY TO BE MISTAKEN FOR THE EUROPEAN CORN-BORER}

In addition to the native borers already mentioned as closely related to the European corn-borer there are several others which might easily be mistaken for it by one not familiar with it.

The Corn Ear-worm.- The most common of the above class is the corn ear-worm, a grayish, brownish, or greenish caterpillar found boring in the ends of the ears of sweet and field corn. When fully grown this caterpillar is about one and a half to two inches long, and varies greatly in its color and markings, some specimens being dark green with very few markings on the back or sides, others a light gray with quite distinct stripes, and still others coming somewhere between these extremes. When placed under the microscope the skin of this caterpillar is seen to be covered with minute, dark, stubbed spines, which readily distinguish it from the European corn-borer, as the latter has no such spines. In addition to this character, the abdominal pseudopods of the ear-worm have an apical tranverse band of hooks, and not an almost complete circle as in the corn-borer. On becoming full-grown the ear-worm enters the ground and changes to a pupal or resting stage, in which it passes the winter, coming out early in spring as a yellowish or yellowish gray moth, with irregular dark spots distributed over the wings. The moth has a wing expanse of about one and a half inches, and flies mostly at night, feeding on the nectar of flowers. It is much more robust than the moth of the European corn-borer the thorax and abdomen being much stouter. The moths are very strong fliers, and, with a good wind behind them, may travel considerable distances, probably several miles. There are three generations of the ear-worm in each season, the moths of the first generation laying their eggs on green, succulent plants and weeds, on the stems or leaves of which the larvae feed. The second generation feed on leaves of various plants, especially on sweet corn. Moths of the third generation appear about the time that the late and medium-late corn is in the fresh silk stage, and deposit their eggs in large numbers on the silks of such corn. These moths vary greatly in abundance from year to year, being usually most abundant after one or two dry seasons. This is one of our most destructive corn insects, especially injurious to sweet corn. Some of the large corn-canning companies in this state have sometimes suffered losses of $\$ 30,000$ to $\$ 40,000$ in a single season, due to the ear-worm. In this state, corn is the principal crop injured by it, but 
it also injures the fruit of the tomato, and in southern Illinois it is a serious pest of tobacco and cotton.

The Fall Army-zorm.-Another insect very likely to be mistaken for the European corn-borer is what is commonly known as the fall army-worm. The larva of this insect has very much the sane external appearance as the corn ear-worm, except that we never find any specimens of a solid green. It is often found feeding in the ends of ears of corn, although it ustually has much the same feeding habits as the true army-worm. It can be distinguished from the corn ear worm by the fact that under the microscope the skin appears smooth with very minute black dots. Like the corn ear-worm, this insect belongs to the night-moth family (Noctuidae), and it has the claws of the abdominal psendopods in a transverse band. It can not survive the winter in Illinois, but the moths migrate northward each year from the Southern States. It occurs herc in really injurious numbers only about one year in five to sever.

The Common Stalk-borer.-Another native borer somewhat resembling the European corn-borer in its manner of feeding is what is generally known as the common stalk-borer. Our attention is usually first attracted to this insect early in spring, by noticing small clumps of dead grass around the margins of fields, along roadsides, and in similar situations. If we examine these carefully, we shall find a very small caterpillar working inside the stems in the center of the clump. These larvae are brown with five white stripes, one down the middle of the back and two on each side. The side-stripes are interrupted for a considerable space near the middle of the body, so that usually one third or more of the body is entirely brown except for the stripe on the back, giving the insect somewhat the appearance of having been crushed or bruised about the middle. As the worms grow they leave the grass and burrow the stems of various weeds and cultivated plants. They frequently migrate into fields of grain or corn, burrowing in the stems of these plants, causing the heads of the grains to whiten and the corn plant to become misshapen, and often preventing the formation of an ear. They become full-grown about the middle of July to the last of August, clianging to the brown pupal or resting stage in the stems of their food plants, and emerging in August and September as dark, grayish brown moths with the outer third of the wing lighter and separated from the inner twothirds by a whitish cross-line. The wing expanse is about one and a half inches. These moths belong to the same family as the two previously mentioned. They fly at night, and lay their eggs in fall about the stems of the various weeds and grasses in the same situations in which the young larvae are found feeding in spring.

There are several other species which resemble the European cornborer in the larval or worm stage. One of these is a tineid. the larva of which occurs in the stens of Spanish needles and other weeds along 
with the smartweed-borer. This species is shown in Figure 8. It may be at once distinguished from the other borers by the presence of three bristles of the infraspiracular spot on the prothorax (Fig. 26), by the
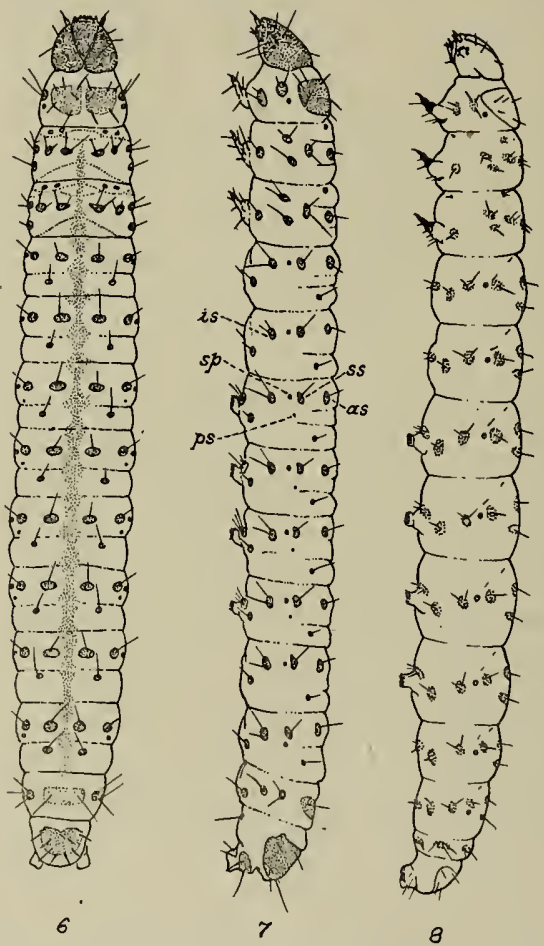

Fig. 6. Larva of Pyreustr mubilalis, dorsal view.

Fig. 7. Larva of Pyrausta nubilalis, lateral view: is, infraspiracular spot: $s s$, supraspiracular spot; $a s$, anterior submedian spot ;

FIG. 8. Tineid larva from stems of Spanish needles (Bidens sp.).

number of bristles on the ninth abdominal segment (Fig. 2r), and by the presence of a complete circle of claws, arranged in a single series, on the abdominal pseudopods. 
Another species which bores in umbelliferous weeds and which also closely resembles the European corn-borer, is a small moth (Depressaria heracleana) of the family Tineidae which occurs in this country and in Europe. Like the tineid mentioned in the preceding paragraph it has three bristles on the infraspiracular spot on the prothorax (Fig. 23), but the bristling of the ninth abdominal segment is very different in the two species (cf. Fig. 27 and Fig. 24).

Briefly stated, there are many species the larvae of which superficially resemble the European corn-borer, but with the exception of the smartweed-borer none of then which are likely to be found in corn in Illinois present all of the group characters enumerated in the next paragraph as distinguishing the European corn-borer and its allies.

Doubtful specimens should always be sent to the Natural History Survey, Urbana, Ill., so that their identity can be established with certainty.

\section{Distinguishing Characters of the Corn-borer Group}

(Pyrausta nubilalis, P. penitalis, and P. obumbratilis.)

Lari'ae.-Body with conspicuous round black or brown setigerous spots, ten on each of the thoracic and abdominal segments except the prothorax and the apical two abdominal segments. These spots are always conspicuous on the dorsum, and in penitalis only are they almost obsolete below the level of the spiracles.

From species which have similar feeding habits the larvae may be distinguished by the following combination of characters: Prothorax with two bristles on infraspiracular and lateroventral spots (Fig. 13, 18), median abdominal pseudopods with an almost complete circle of small curved apical hooks which are arranged in three series at the broadest part of the circle (Fig. 21, 22), a small brown chitinized spot a short distance caudad of the spiracle on each of the segments which bear the pseudopods, supraspiracular spot on ninth segment with two bristles, the dorsum with a large transversc chitinized plate which bears two bristles, ocelli six in number, subequal in size, skin with nimute chitinized dots at least on dorsum but wihout protuberances.

Pupae.-Pygofers present but not very pronounced, fore femora exposed, tarsi not exceeding apices of wing-cases, apical segment with a number of curved bristles resembling small hooks; abdomen with very few hairs, and without distinct protuherances other than some very minute paired teeth on each side of the median line on dorsum.

Adults.-The group belongs to the family Pyralidae, subfamily Pyraustinae, genus Pyrausta. The species are very similar in general appearance, being yellowish or brownish with the basal and submarginal lines brown as a general rule, but in the case of nubilalis and some specimens of penitalis there is a tendency to have the fore wings with a more 
or less distinct broad central dark fascia between the dentate lines. In all three species the hind wings have distinct markings.

Not infrequently specimens of larvae, pupae, or adults are found under circumstances which suggest the possibility of their being the European corn-borer, and in order to decide whether or not they do belong to that species it is necessary to subject the specimens, at least the larvae or pupae, to a careful microscopic examination. The principal character by means of which the European species may be distinguished from its nearest allies is fortunately almost invariably perceptible by means of a hand lens with a magnification of ten diameters. The specific characters enumerated in this paper have been ascertained from an exhaustive examination of large series of specimens of the three species involved.

\section{The European Corn-Borer}

\section{(Pyrausta nubilalis Hüb.)}

Larva (Fig. 6, $\%$ ).-In the size and comparative distance between the anterior submedian dorsal spots on the abdomen this species approaches very closely to penitalis, but the minute chitinized points on the skin surface are continued much below the level of the spiracles and the infraspiracular and lateroventral spots are conspicuously blackish or brownish. Bristles of the prothorax and of the eighth and ninth abdominal segments as in Figures 13, 14, and 15.

From obumbratilis (Fig. 9, $5 a$ left) this species may, almost invariably be distinguished by the much more widely separated anterior submedian dorsal spots on the abdominal segments (Fig. 5a right, 10), these being separated by a much greater distance than the diameter of one spot, by the almost uniformly colored lateroventral spots (Fig. 16), the arrangement of the bristles laterocephalad of the abdominal pseudopods (Fig. 21) ; under a very high power lens, by the less compact nature of the chitinized points on the skin, their less close approximation to each other, and the less complete series of dots in the interspaces (Fig. 12) ; and, seen under a very high power, the arrangement of the hairs and the small puncture slightly above the level of the ocelli differ from the same in abumbratilis as shown in the composite Figure 25, left side of figure.

PLATE XXIX.-Fig. 9. Pyrausta obumbratilis, second and third abdominal segments, from above. Fig. 10. Pyrausta nubilalis, the same. Fig. 11. Pyrausta obumbratilis, skin surface, highly magnified. Fig. 12. Pyrausta nubilalis. same. Fig. 13, 14, 15. $P$. nubilalis, prothorax, and 8 th and 9 th abdominal segments, from the side. Fig. 16. $P$. nubilatis, lateroventral spot. Fjg. 17. P. obumbratilis. same. Fig. 18. 19. 20. $P$. penitalis, prothorax and 8 th and 9 th abdominal segments, from the side. Fig. 21. P. nubilalis, abdominal pseudopod. Fig. 22. P. obumbatilis, same. Fig. 23, 24. Depressaria heracleana. prothorax and 9 th abdominal segment, from the side. Fig. 25. Composite head of Pyrausta: nubilalis. left side of flgure ; obumbratilis, right side. Fig. 26, 27. Tineid sp., prothorax and 9 th abdominal segment of larva, from the side. 
Plate XXIX

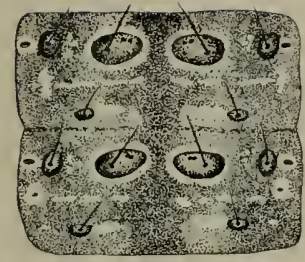

9
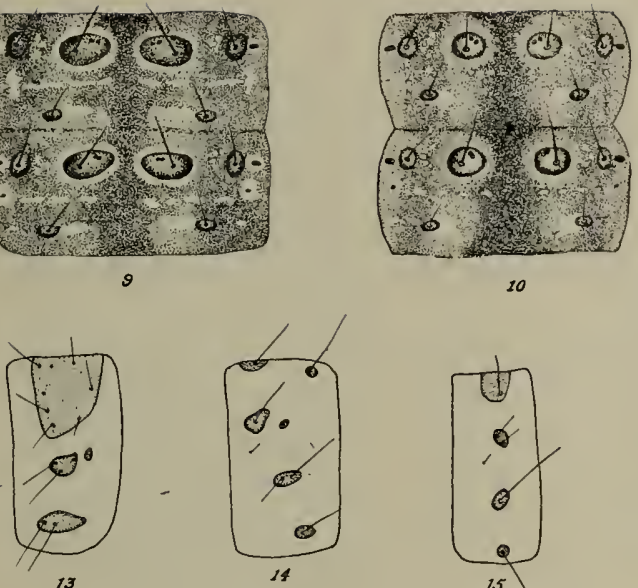

13
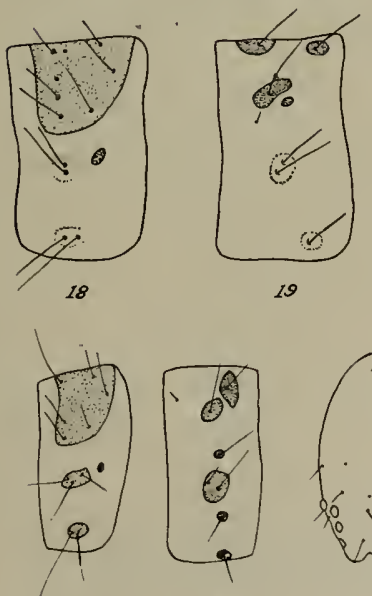

23

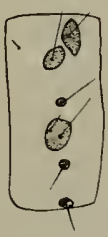

24
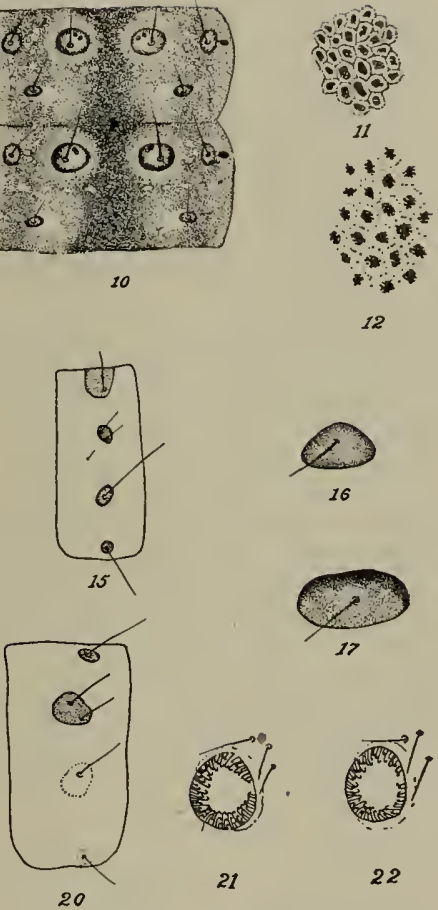

21

22

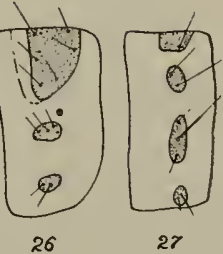


Plate XXX
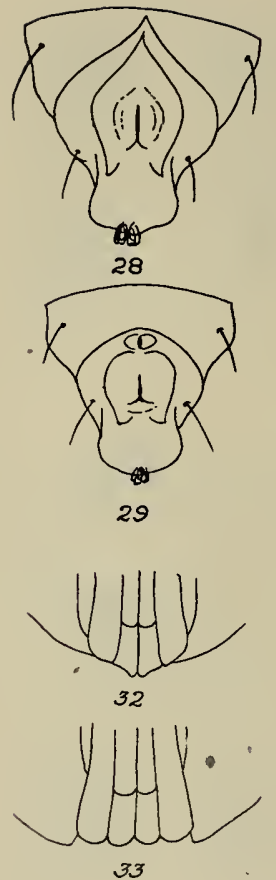

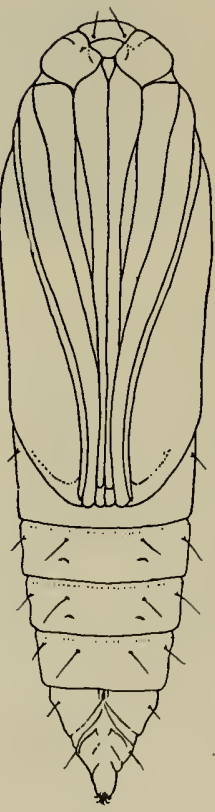

34

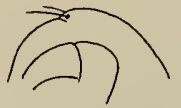

37
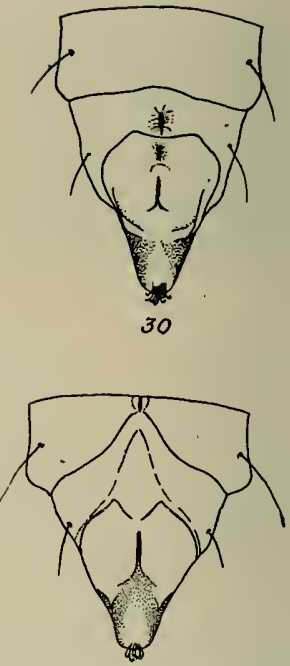

31

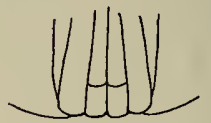

35

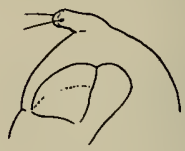

38

PLATE XXX.-Fig. 28, Pyrausta penitalis, apex of pupa of female. Fig. 29. P. penitalis, same of male. Fig. $30 . P$. nubilalis, apex of pupa of male. Fig. $31 . P$. nubilalis, same of female. Fig. 32. P. penitalis, apices of thoracic and cephalic appendages of pupa, male, Fig. 33. $P$. penitalis, the same of female. Fig. 34. $P$. nubilalis, pupa, male. Fig. 35. P. nubilatis, apices of thoracic and cephalic appendages, male. Fig. 36 . $P$. obumbratilis, the same, female. Fig. 37. P. nubilalis, pupa, side view of cephallc extremity. Fig. 38. $P$. obumbratilis, the same. 
Pupa (Fig. 34).-The pupa is readily distinguished from that of obumbratilis by the absence of the blunt protuberance on the head (Fig.

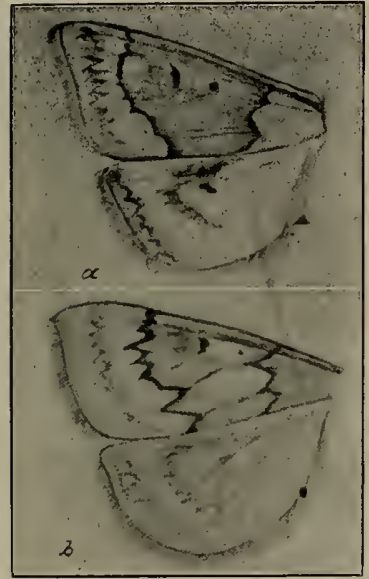

F1G. 39. Wings of the left slde $(a)$ of Pyrausta nubilalis, female and $(b)$ of $P$. penilalis, female. 37,38 ). In general it more closely resembles penitalis, but the dorsal abdominal segments, have distad of the fine bristles two pairs of minute teeth on each side of the median line. These teeth are very much smaller in penitalis and obumbratilis than in nubila lis. The apical segment in both sexes of nubilalis is much narrower than in penitalis, as shown in Figures 30 and 31 . In the comparative lengths of the maxillae and antennae there is but little difference between nubilalis (Fig. 35) and penitalis, but in obumbratilis the antennae and maxillae are considerably shorter than in the other two species.

Adult.-This species is the darkest of the group, the male in particular being very dark. We have figured the wings of the female (Fig. $39, a)$. In the male the central band of fore wings, the base proximad of the indented line, and the tip beyond the submarginal line are usually dark brown, leaving only two narrow notched yellow fasciae, one before and the other beyond the middle. The hind wings of the male are much darker than those of the female, the only yellow portion being a moderately broad band across middle.

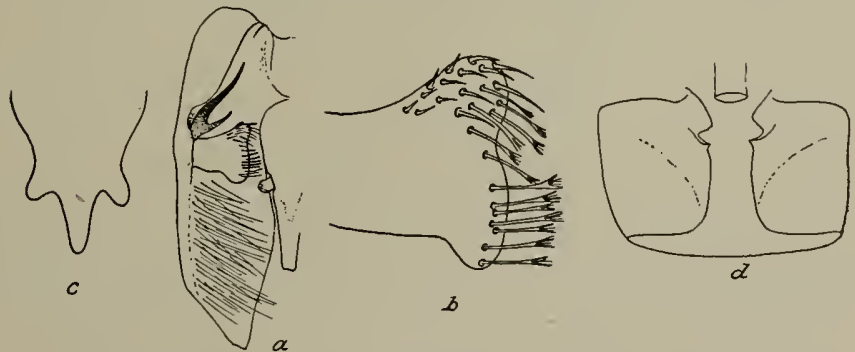

Fig. 40. European corn-borer (Pyrauste mubilalis): $a$, male hypopygium, one side: $b$, central process, more enlarged; and $c$, dorsal plate. Female penultimate abdominal segment, $d$. 
The face is produced but little beyond anterior margin of eyes in profile, is convex, with an almost imperceptible carina at anterior margin, beyond which it is declivitous. The male hypopygium is as shown in Figure 40 , the strong appendiculate thorn above middle of each clasper being very differem from the two small thorns present in obumbratilis. The process at middle of each clasper (Fig. 40:) is more like that of obumbratilis than that of penitalis. In the specimens before me the submarginal line in fore wings is less distinctly dentate posteriorly than in any of the other three species (Fig. 39, $a$ ).

\section{The Nelumbo-Borer (Pyrausta penitalis Grote)}

Larva.-The dark chitinized points on the skin, which form the color pattern on the dorsum and sides of the other two species are not continued below the level of the spiracles in penitalis, and the infraspiracular and lateroventral spots are not darker than the surrounding skin, though chitinized (Fig. 18, 19, 20). The anterior submedian dorsal spots on the abdomen are separated by much more than the width of one of the spots as is the case in mubilalis. The prothorax has the small chitinized points proximad of the dorsal plate much more evident than in either of the other species.

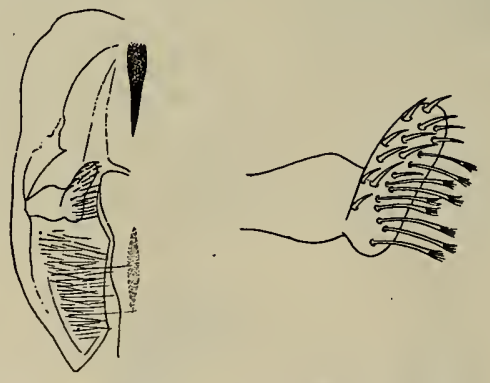
Fig. 41. Nelumbo-borer (Pyrausta penitalis):
male hypopygium, one side, and median process much more enlarged.

Pupa.-Distinguishable from nubilalis by the much broader apical segment in both sexes (Fig. 28, 29), and the smaller paired teeth beyond the bristles on the dorsal segments of the abdomen. Apices of thoracic and cephalic appendages as in Figures 32 and 33.

Adult-Larger than obumbratilis, usually averaging as large as nubilalis, $27-35 \mathrm{~mm}$. in expanse of wings. Freshly emerged specimens are more reddish than any of the other species included in this paper. The 
submarginal line is more pronouncedly dentate than in nubilalis (Fig. 39, b).

The face is much more distinctly produced than in nubilalis, the anterior margin being carinate and more or less distinctly arched in middle, sometimes almost pointed above. The male hypopygium differs from that of nubilalis in having no thorns above at middle of claspers and the process differently shaped (Fig. 41).

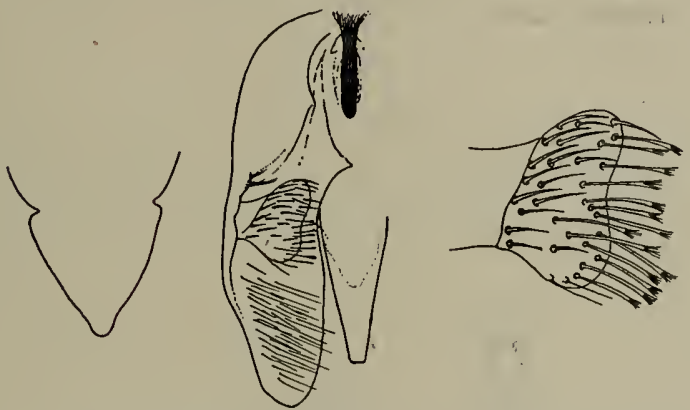

Fig. 42. Smartweed-borer (Pyrausta obumbratilis): male hypopygium. one side; median process (right) much more enlarged; and (left) dorsal plate.

\section{The SmartweEd-Borer}

(Pyrausta obumbratilis Led.)

Larva.-More slender than either of the other two species and normally more conspicuously spotted, the spots larger and darker.

Differs from nubilalis in having the anterior submedian dorsal spots on abdomen separated by less than the diameter of one spot (Fig. 9), the ventrolateral spot with a conspicuous lunate black upper margit (Fig. 17), the bristles cephalolaterad of the pseudopods differently arranged (Fig. 22), and the small chitinized dots on the skin less evidently composed of minute contiguous points, the dots being separated on the greater portion of the body by less space than the diameter of a dot. the series of minute points in the intervening spaces being more complete (Fig. 11) ; and the bristles near ocelli (Fig. 25, right side) being differently arranged.

Pupa.-Distinguishable from either of the other two species by the prominent protuberance on the head as shown in Figure 38 . The apical abdominal segment is very similar to that of mubilalis, but the small 
paired teeth on the dorsum of the abdomen are much smaller in this species. Apices of thoracic and cephalic appendages as in Figure 36.

Adult.- Much paler than nubilalis. The submarginal line is much more deeply indented, being similar to that of penitalis. The male hypopygium has two small thorns instead of the long stout appendiculate thorn which is present in nubilalis (Fig. 42), and the process at middle of the clasper is slightly different in shape and more numerously bristled (Fig.. 42). The face is not so much elevated at anterior margin as in penitalis, but has a slight carina beyond which it is declivitous. Usually the specimens average smaller than those of the other two species.

\section{Pyrausta caffreii, sp. n.}

Adult.-This species closely resemble obumbratilis, the color and markings being very similar. The general color of the fore wings of the two females before me is a clear straw-yellow, with the markings linear and pale brown. The male which $\mathrm{I}$ have is badly deformed and the wings, owing to their being only partially developed, are darker than in the females, having many brownish scales apically. It is not possible to
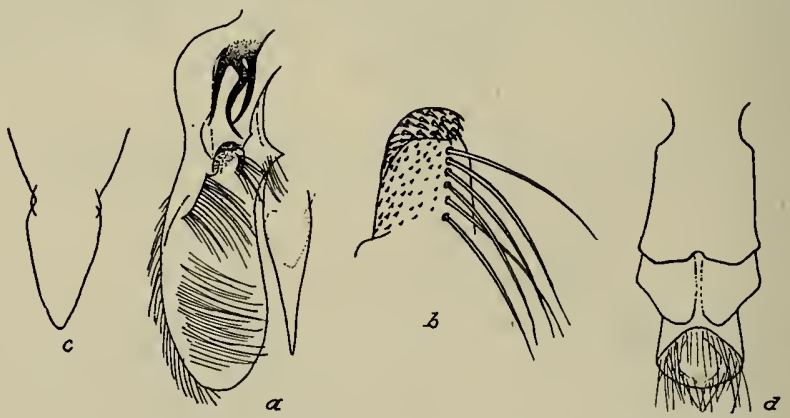

Fig. 43. Pyrausta caffreii: $a$, male hypopygium, one side; $b$, central process, more enlarged; and $c$, dorsal plate. Female genital segments, $d$.

describe the wing markings from the male but those of the female are almost identical with those of obumbratilis, the submarginal line being deeply indented posteriorly. The male hypopygium is strikingly different from that of any of the other three species as shown in Figure 43. The principal distinction lies in the presence of three long spines arising from a common base at base of each clasper. In addition to this there are striking differences in the shape of the process at middle of the clasper and in its surroundings. The face in both sexes is almost conically produced and 
very different from that of any of the other species (Fig. 1t). Female apical segments as in Figure 43.

IVe consider it/proper to assign a name to this very well-defined species though it may eventually prove to have been already described. A careful examination of the hypopygia of all the species in the genus is essential to a clearing up of the synonymy.

Type, male, Bloomington, Ill., September 30,1919 , taken in a field of sweet corn which was destroyed by larvae of the fall army-worm (J. R. Nalloch). Allotype and one female paratype without locality labels.

Named in honor of Mr. D. J. Caffrey, who kindly supplied much of the material for the study of nubilalis.

The immature stages and food plant of this species are unknown - to us at this time.

For the identification of obumbratilis we are indebted to Dr. IV. T. M. Forbes who, on a visit here some months ago, thus identified several specimens in our collection, some of which had been reared from cornstalks in which the larvae had evidently passed the winter. This species was not included in the Twenty-third Report of the State Entomologist"A Monograph of Insects Injurious to Indian Corn"-as its habits were not known here until a year after that report appeared, the first Illinois specimen being reared in 1906 .

After this paper had been prepared for the press and before it was sent to the printer there appeared in the Journal of Agricultural Research a paper by Carl Heinrich on the European corn-borer in which the name $P_{y}$ rausta ainslici is given to the species here designated as obumbratilis. We have examined the series of obumbratilis in the collection of Dr. $1 \mathrm{~mm}$. Barnes, which contains some specimens reared by Kearfott from Typha (cattail-flag), and after comparing the genitalia of one of the males of the reared series

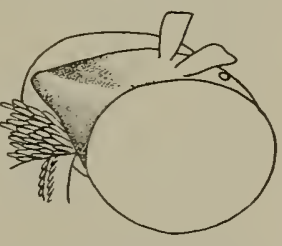

Fig. 44. Pyransta caffreii, head of male from side: palpi, antennae, and proboscis incomplete. with some of those in our collection we are convinced that they are identical with ainslici Heinrich. The basal spine, which is not figured by Heinrich, is easily detached from the genitalia in dissection, and is really present in the species he figures but evidently was lost in dissecting the specimen.

\section{ERRATUM}

Fig. 5a, page 293, was reversed in printing; the two items of the legend should change places. 